\title{
Impact of COX2 Inhibitor for Regulation of PD-L1 Expression in Non-small Cell Lung Cancer
}

\author{
KATSUHIKO SHIMIZU, RIKI OKITA, SHINSUKE SAISHO, AI MAEDA, YUJI NOJIMA and MASAO NAKATA \\ Department of General Thoracic Surgery, Kawasaki Medical School, Kurashiki, Japan
}

\begin{abstract}
Background/Aim: There is no clear evidence in the literature regarding the regulation of programmed cell death-ligand 1 (PD-L1) expression by cyclo-oxygenase-2 (COX2). In this study, whether PD-L1 expression was regulated by $C O X 2$ activity was examined in vitro. Materials and Methods: Resected lung cancer specimens were analyzed for PD-L1 and COX2 expression by immunohistochemical analysis. Next, co-localization of $P D$ L1 and COX2 expression was analyzed by doublefluorescence staining. Lastly, the effect of COX2 inhibition on the expression of $P D-L 1$ was examined using lung cancer cell lines. Results: PD-L1 expression was significantly correlated with COX2 expression in the resected specimens. The majority of cancer cells that expressed PD-L1 also coexpressed COX2. However, treatment of lung cancer cell lines with a COX2 inhibitor had no impact on PD-L1 expression. Conclusion: Our results suggest that COX2 inhibition might have no effect on the usage of immune checkpoint inhibitors in lung cancer treatment.
\end{abstract}

In recent years, the development of new and more effective cancer immunotherapy has partially improved the prognosis of patients with advanced non-small cell lung cancer (NSCLC) $(1,2)$. Programmed cell death-1 (PD-1) is a T-cell co-inhibitory receptor with ligand specificity for PD-ligand 1 (PD-L1) and PD-L2. PD-1 and PD-L1 are well-known as immune checkpoint inhibitory molecules. Binding of PD-1 with PD-L1 results in inhibition of T-cell activation and proliferation $(3,4)$. To date, several studies have reported that tumor overexpression of PD-L1 is a predictor of a poor clinical outcome in patients with NSCLC (5-7), whereas it was also correlated with an improved response to treatment with

Correspondence to: Katsuhiko Shimizu, Department of General Thoracic Surgery, Kawasaki Medical School, 577 Matsushima, Kurashiki, Okayama 701-0192, Japan. Tel: +81 864641124, Fax: +81864641124, e-mail: kshimizu@med.kawasaki-m.ac.jp

Key Words: Non-small cell lung cancer (NSCLC), PD-L1, COX2, COX2 inhibitor, co-localization. immune checkpoint inhibitors (8-11). Cyclooxygenase-2 (COX2) is an inducible enzyme that is activated by growth factors and pro-inflammatory cytokines (12). Past epidemiological studies have indicated that prolonged COX2 inhibition, such as through aspirin or non-steroidal antiinflammatory drugs, could offer some protection against colorectal, breast, and other cancer types $(13,14)$. In NSCLC treatment, immune checkpoint inhibitors are now widely used. In contrast, COX2 inhibitors are commonly used drugs for pain control. However, to date, the relation of $\mathrm{COX} 2$ with regulation of PD-L1 expression is still unknown.

We previously examined the expression of three biomarkers in resected specimens of lung adenocarcinoma: PD-L1, COX2, and tumor-infiltrating lymphocytes (TILs) (15). We reported that tumors with high PD-L1 expression had a significantly larger number of TILs than those with low expression; in contrast, tumors with high COX2 expression had significantly fewer TILs than those with low expression. We also suspected that PD-L1 and TILs status might indicate the effects of COX2 inhibitor. In order to clarify this point, whether COX2 expression was correlated with PD-L1 expression in resected lung adenocarcinoma specimens, and whether the PD-L1 expression in lung cancer cell lines is regulated by COX2 activity were examined.

\section{Materials and Methods}

Tumor samples. We previously examined the expression of PD-L1 and COX2 in resected tumor specimens of 170 patients with clinical T1-2 N0 M0 lung adenocarcinoma (15). Of these, 16 patients with both very high PD-L1 and COX2 expression levels were enrolled in this study. Written informed consent for the study of the excised tumor samples was obtained from each patient. This study was conducted with the approval of the Ethics Committee of Kawasaki Medical School (No. 2762).

Immunohistochemical (IHC) analyses and assessment. IHC analyses were performed on paraffin-embedded lung cancer tissue specimens. After microtome sectioning (into $4-\mu$ m-thick sections), the slides were processed for staining using an automated immunostainer (Nexes; Ventana, Tucson, AZ, USA). The primary antibodies were used according to the manufacturer's instructions. IHC was performed using the following primary antibodies: mouse 
monoclonal anti-PD-L1 (clone 28-8, ab205921, 1: 50 dilution; Abcam, Cambridge, MA, USA) and COX2 (clone CX-294, 1: 50 dilution; Dako Agilent Technologies, Inc., Santa Clara, CA, USA). PD-L1 expression was deemed positive when the tumor cell membrane showed staining of any intensity. The percentage of positively stained cells in a section that contained at least 100 tumor cells was used to calculate the tumor proportion score (TPS). TPS of $5 \%$ or more was defined as high PD-L1 expression (9). For $\mathrm{COX} 2$, the slides were scored according to the intensity of staining (as $0-3)$ and the percentage of positively stained cells $(0,0 \% ; 1,1-$ $9 \% ; 2,10-49 \%$; and $3,50-100 \%)$. The $H$-score was calculated as the product of the intensity and percentages (as 0-9). High COX2 expression was defined as an $H$-score $\geq 4$ (16). The slides were examined by two investigators who were blinded to the corresponding clinicopathological data. Representative sections of PD-L1 and COX2 staining are shown in Figure 1.

Immunofluorescence staining. Double-fluorescence staining for PD$\mathrm{L} 1$ and $\mathrm{COX} 2$ was conducted in 16 representative tumor tissue sections showing positive staining for both PD-L1 (clone 28-8) and COX2 (clone CX-294). Following deparaffinization and hydration, the prepared slides were incubated for antigen retrieval in a pressure cooker (Biocare Medical, Concord, CA, USA) for $10 \mathrm{~min}$ at $110^{\circ} \mathrm{C}$. Following incubation with protein blocking solution, the slides were incubated with a cocktail of PD-L1-and COX2-specific monoclonal antibodies at room temperature. Primary antibodies were detected using a cocktail of goat anti-mouse IgG dylight 488 and goat antirabbit IgG dylight 594. After the slides were washed twice, the nuclei were stained with 4',6-diamidino-2-phenylindole (DAPI) at room temperature for $10 \mathrm{~min}$. Finally, the slides were examined under a fluorescence microscope (Nikon Eclipse E800 Microscope with Digital Imaging Accessories).

Cell lines and reagents. Human A549 (adenocarcinoma, epidermal growth factor receptor (EGFR) wild-type, low PD-L1 expression), LC-2/ad (adenocarcinoma, EGFR wild-type, high PD-L1 expression), PC9 (adenocarcinoma, EGFR mutated) and RERF-LCAI (squamous cell carcinoma, $E G F R$ wild-type) cell lines were used for the in vitro assay; A549, LC2/Ad, and RERF-LC-AI were obtained from Riken BRC through the National BioResource Project of the Ministry of Education, Culture, Sports, Science and Technology (Tsukuba, Japan), and PC-9 was obtained from the Immuno-Biological Laboratories cell bank (Gunma, Japan). All cell lines were authenticated by genotyping with the PowerPlex 16 STR system (Promega, Madison, WI, USA) and maintained as previously described (18). COX2 inhibitor, celecoxib, and the Janus kinase (JAK) inhibitor, tofacitinib, were purchased from Selleck Chemicals (Houston, TX, USA). Interferon- $\gamma$ (IFN- $\gamma$ ) was purchased from R\&D Systems (Minneapolis, MN, USA).

Cell culture. All the cell lines were maintained in culture in RPMI1640 medium (Sigma-Aldrich, St. Louis, MO, USA) with $2 \mathrm{mM} \mathrm{L-}$ glutamine (Invitrogen, Carlsbad, CA, USA) supplemented with $10 \%$ fetal bovine serum (FBS; Gibco by Life Technologies, Grand Island, $\mathrm{NY}, \mathrm{USA}$ ), and $50 \mathrm{U} / \mathrm{ml}$ penicillin streptomycin (Sigma-Aldrich) at $37^{\circ} \mathrm{C}$ in a with $5 \% \mathrm{CO}_{2}$ atmosphere.

Four NSCLC cell lines were treated with 1-30 $\mu \mathrm{M}$ of celecoxib for $24 \mathrm{~h}$, then the expression of PD-L1 was evaluated by flow cytometric analysis. Moreover, NSCLC cells lines A549 and RERFLC-AI were pretreated with $10 \mu \mathrm{M}$ of celecoxib or $1 \mu \mathrm{M}$ of tofacitinib for 2 hours, followed by $0.5 \mathrm{ng} / \mathrm{ml}$ of IFN- $\gamma$ for $24 \mathrm{~h}$, then the expression of PD-L1 was assessed by flow cytometry. Each experiment was repeated at least three times

Flow cytometry to assess the expression of PD-L1 in NSCLC cell lines. Extracellular staining was performed with fluorochromeconjugated antibodies according to standard protocols, as previously described $(17,18)$. The following antibodies were used for flow cytometry: phycoerythrin (PE)-labeled PD-L1 (clone 29E.2A3), and isotype control PE-labeled antibody, which were obtained from BioLegend (San Diego, CA, USA). Cells were acquired on a FACSCanto II flow cytometer with the FACSDiva software (BD Biosciences, San Diego, CA, USA), and the analysis was conducted using the FlowJo software 6.4.7 (Treestar, Ashland, OR, USA).

Statistical analysis. All the statistical analyses were performed using the SPSS statistical package (version 17.0; SPSS, Chicago, IL, USA). Chi-square test or Fisher's exact test was performed to compare the expression levels of PD-L1 and COX2 among patients. In all tests, a value of $p<0.05$ was considered as denoting statistical significance.

\section{Results}

IHC characteristics. The IHC PD-L1 and COX2 expression levels in the 170 tumor specimens are reported in Table I. IHC analysis revealed high PD-L1 expression ( $\geq 5 \%$ of the cells) in 59 specimens $(34.7 \%)$, and high COX2 expression $(H$-score $\geq 4)$ in 78 cases $(45.9 \%)$. A significant positive correlation was observed between PD-L1 and COX2 expression $(p=0.035)$. Of these, 16 patients whose tumor specimens showed very high PD-L1 expression levels (TPS $\geq 50 \%)$ and very high COX2 expression levels $(H$-score $\geq 6$ ) were examined for co-localization.

Co-localization of PD-L1 and COX2 in lung adenocarcinoma tissues. We then investigated whether single lung cancer cells expressing PD-L1 also co-expressed COX2. Double-immunofluorescence staining utilizing both PD-L1 and COX2-specific monoclonal antibodies was performed on 16 representative lesions, and representative staining patterns of two typical primary lesions are shown in Figure 2. The majority of cancer cells that expressed PD-L1 also co-expressed $\mathrm{COX} 2$ in all cases.

Effect of COX2 inhibition on PD-L1 expression in NSCLC cell lines. We next used four NSCLC cell lines to evaluate whether celecoxib affected the expression of PD-L1 in NSCLC. All the cell lines were treated with the selective COX2 inhibitor celecoxib at different doses for 24 hours, and PD-L1 expression was assessed by flow cytometry. Celecoxib was found to have no effect on the basal expression of PD-L1 in the NSCLC cell lines examined (Figure 3). IFN- $\gamma$ is known to induce PD-L1 expression $(20,21)$. Zang et al. reported that PD-L1 was induced by IFN- $\gamma$ released from tumor-associated macrophages via the 

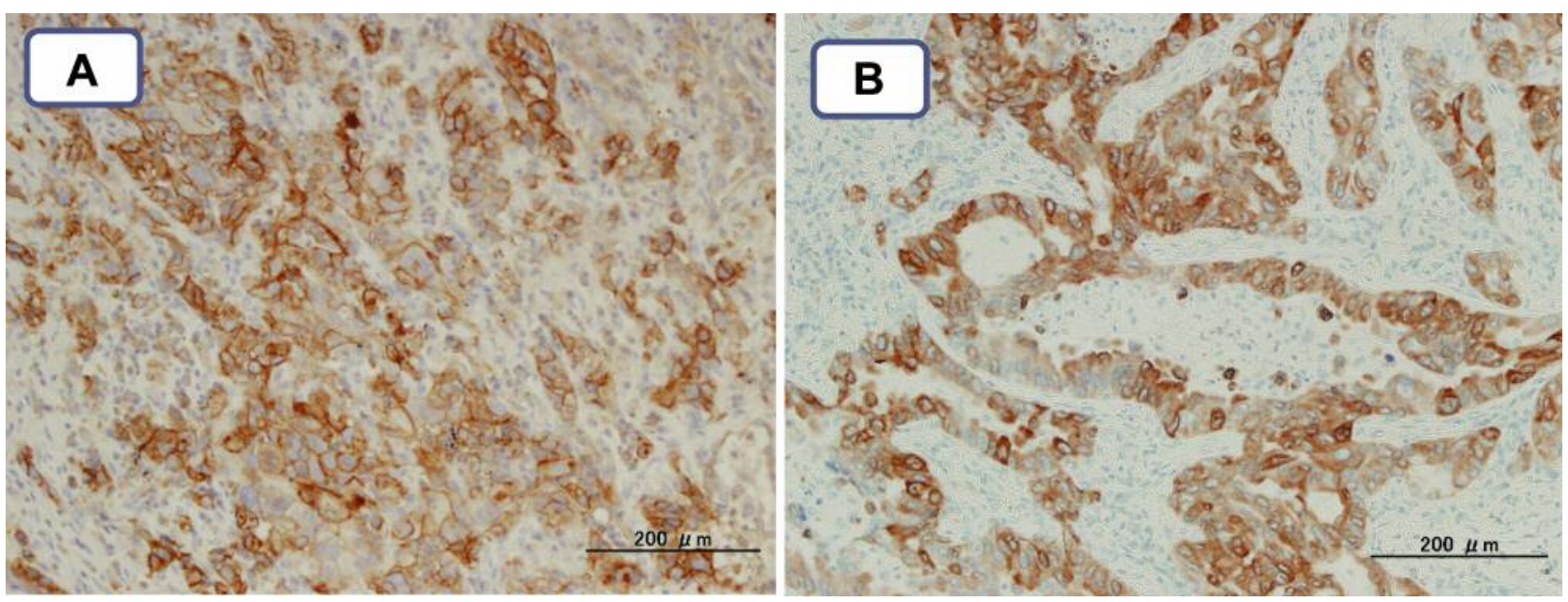

Figure 1. Representative sections of lung adenocarcinoma tissues with strong membranous staining for programmed cell death-ligand 1 (PD-L1) (A), and strong cytoplasmic staining for cyclo-oxygenase-2 (COX2) (B).
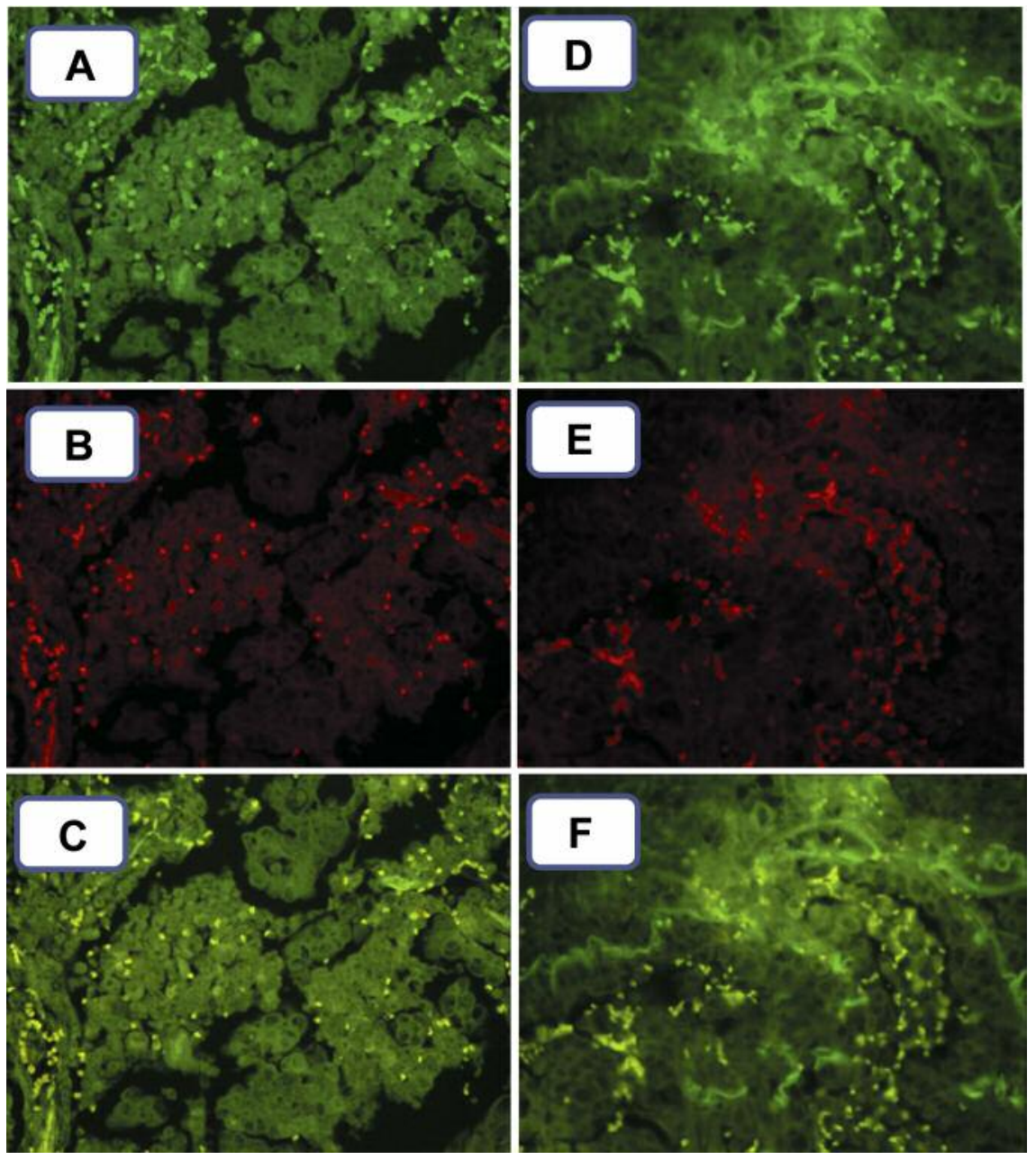

Figure 2. Representative matched immunofluorescence staining of lung tumors with cyclo-oxygenase-2 (COX2)-specific (clone CX-294) (A, D), PDL1-specific (clone 28-8) $(B, E)$ and both COX2-and PD-L1-specific $(C, F)$ monoclonal antibodies. COX2 was detected with goat anti-mouse IgG dylight 488 (green). Immunofluorescence staining of PD-L1 was detected with goat anti-rabbit IgG dylight 594 (red). 
JAK/signal transducer and activator of transcription (STAT3) and phosphoinositide 3-kinase (PI3K)/AKT signaling pathways in lung cancer cells (22). Next, we investigated whether IFN- $\gamma$-induced PD-L1 was blocked by celecoxib in NSCLC cell lines. As expected, JAK inhibitor tofacitinib blocked IFN- $\gamma$-induced PD-L1 expression in the cell lines (Figure 4A) whereas, on the other hand, celecoxib did not block IFN- $\gamma$-induced PD-L1 expression (Figure 4B). These results suggest that $\mathrm{COX} 2$ has no impact on basal nor IFN$\gamma$-induced PD-L1 expression in NSCLC.

\section{Discussion}

Recently, development of inhibitors of immune checkpointinhibitory molecules such as PD-1 and PD-L1 has revolutionized the treatment of advanced NSCLC. Several clinical trials have shown that immune checkpoint inhibitors increase the response rate and survival of advanced patients with NSCLC, especially those with tumor PD-L1 overexpression $(8-11,22)$. Significant effort is currently being invested in evaluating novel combinations of PD-1 or PD-L1 inhibitors with other immunotherapeutic agents or treatment modalities, such as chemotherapy and radiation therapy.

Several studies have reported that COX2 is constitutively overexpressed in a variety of cancer types, such as of the lung, breast, pancreas, colon, esophagus, and head and neck, and tumor COX2 overexpression is usually associated with a poor outcome (23-25). In 2010, we demonstrated that the tumor-infiltrating regulatory T-cell count was positively correlated with COX2 expression, and was also associated with survival (26). COX2 is currently being investigated as a potential therapeutic target. For example, Edelman et al. reported that $\mathrm{COX} 2$ expression was a significant prognostic factor in patients with advanced NSCLC. Moreover, patients with moderate to high tumor COX2 expression treated with celecoxib showed better treatment outcomes, including better local tumor responses and prolonged survival, compared to those not treated with celecoxib (16). On the other hand, in the NVALT-4 study, COX2 expression was not identified as a prognostic biomarker and had no predictive value even when celecoxib was added to chemotherapy (27). Thus, in the treatment of NSCLC, the usefulness of COX2 inhibitors remains controversial and requires further investigation (28).

There are still many unclear points regarding the significance of the relationship between PD-L1 and COX2. In this study, we demonstrated the following: i) PD-L1 expression was correlated with COX2 expression in resected tissue specimens of lung adenocarcinoma; ii) the majority of cancer cells expressing PD-L1 also co-expressed COX2; iii) COX2 inhibition had no impact on PD-L1 expression in NSCLC cell lines as assessed in vitro. To date, there are two studies that have reported the regulation of PD-L1 expression by COX2. The first, published in 2009 by Liang et al.,
Table I. Relationship between programmed cell death-ligand 1 (PD-L1) and cyclo-oxygenase-2 (COX2) expression $(n=170)$.

\begin{tabular}{lc}
\hline Variable & Number $(\%)$ \\
\hline PD-L1 TPS (\%) & \\
0 & $46(27.1)$ \\
$1-4$ & $65(38.2)$ \\
$5-9$ & $21(12.3)$ \\
$10-49$ & $20(11.8)$ \\
$\geq 50$ & $18(10.6)$ \\
PD-L1 expression status & \\
Low expression (TPS $=0-4)$ & $111(65.3)$ \\
High expression $(\mathrm{TPS} \geq 5)$ & $59(34.7)$ \\
COX2 H-score & $16(9.4)$ \\
0 & $76(44.7)$ \\
$1-3$ & $32(18.8)$ \\
4 & $35(20.6)$ \\
6 & $11(6.5)$ \\
9 & \\
COX2 expression status & $92(54.1)$ \\
Low expression $(\mathrm{H}-\mathrm{score}=0-3)$ & $78(45.9)$ \\
High expression $(\mathrm{H}-\mathrm{score} \geq 4)$ & \\
\hline
\end{tabular}

TPS: Tumor proportion score.

reported that the COX2 inhibitor nimesulide inhibited IFN$\gamma$-induced PD-L1 expression in breast cancer cells (29). The second, by Botti et al., described that melanoma cancer cells expressing higher levels of COX2 also co-expressed PD-L1 at higher levels, and inhibition of COX2 activity by celecoxib down-regulated PD-L1 expression (30). Findings i) and ii) of our study were similar to the observation in breast cancer or melanoma, however, finding iii) differed from those in the latter two malignancies. The experimental results can be interpreted as suggesting that COX2 inhibition has no effect on PD-L1 expression, and that, therefore, COX2 inhibition has little influence of the efficacy of immune checkpoint inhibitors in lung cancer treatment.

To date, two pathways are well known to regulate PD-L1 expression. $\mathrm{COX} 2$ and the prostaglandin $\mathrm{E}_{2}\left(\mathrm{PGE}_{2}\right)$ pathway were found to regulate PD-L1 expression in tumor-associated macrophages and myeloid-derived suppressor cells (31). On the other hand, existence of a relationship between COX2 activity and activation of the AKT/STAT3 or nuclear factorkappa B (NF-kB) pathways was also reported (32-34). Future studies addressing the molecular signals underlying the regulation of PD-L1 expression by COX2 in cancer cells might shed light for developing novel therapeutic agents to modulate cancer cell immune responses.

This study had several limitations that should be considered when interpreting the results. The major limitations were the retrospective study design and relatively small number of enrolled patients. Further accumulation of data is needed. 

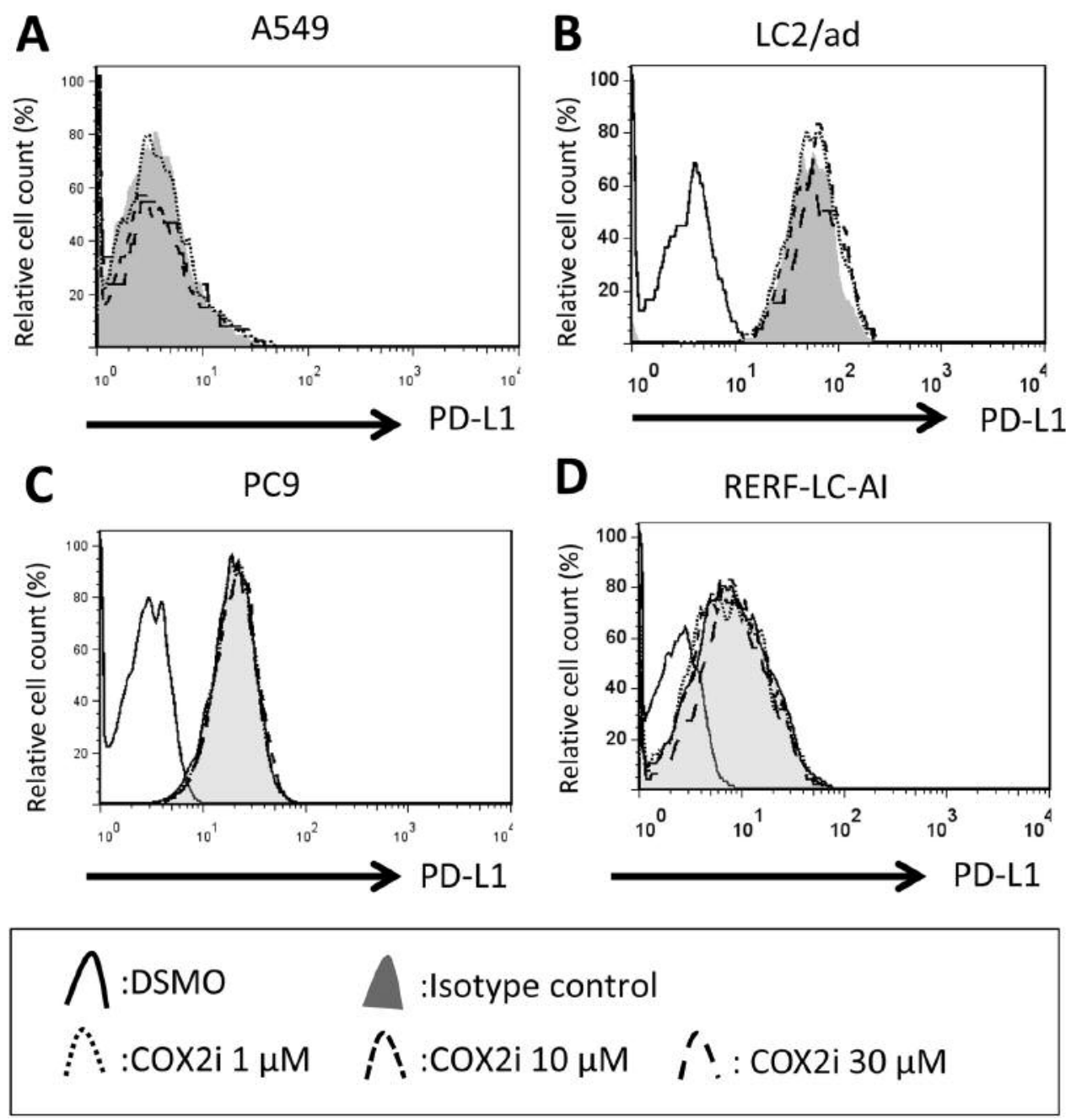

Figure 3. Cyclo-oxygenase-2 (COX2) inhibition did not attenuate programmed cell death-ligand 1 (PD-L1) expression in non-small cell lung cancer (NSCLC) cell lines. PD-L1 expression was assessed by flow-cytometry in four NSCLC cells treated with 10-30 $\mu M$ of celecoxib for 24 h (A-D). Representative data from at least three independent experiments are shown.

In conclusion, PD-L1 expression was significantly correlated with COX2 expression in resected lung adenocarcinoma specimens, and the majority of cancer cells that expressed PD-L1 also co-expressed COX2. However, treatment with a COX2 inhibitor had no impact on PD-L1 expression in the NSCLC cell lines studied here. Our results suggest that COX2 inhibition might have no effect on the usage of immune checkpoint inhibitors in lung cancer treatment.

\section{Conflicts of Interest}

Dr. M. Nakata received research funding from Ono Pharma for this study. The sponsors had no control over the interpretation, writing, or publication of this work. All other authors declare no conflicts of interest.

\section{Acknowledgements}

The Authors thank Ms. Keiko Isoda and the staff of the Tissue Culture \& Immunology and the Tissue Biology \& Electron Microscopy Research Centers (Kawasaki Medical School) for providing technical assistance. The Authors would like to thank IMIC (http://www.imic.or.jp/) for the English language review. This work was supported by the Japanese Society for the Promotion of Science (JSPS) Kakenhi Grants [grant numbers 16K10696 to R.O.]

\section{References}

1 Cho JH: Immunotherapy for non-small-cell lung cancer: current status and future obstacles. Immune Netw 17: 378-391, 2017.

2 Malhotra J, Jabbour SK and Aisner J: Current state of immunotherapy for non-small cell lung cancer. Transl Lung Cancer Res 6: 196-211, 2017. 

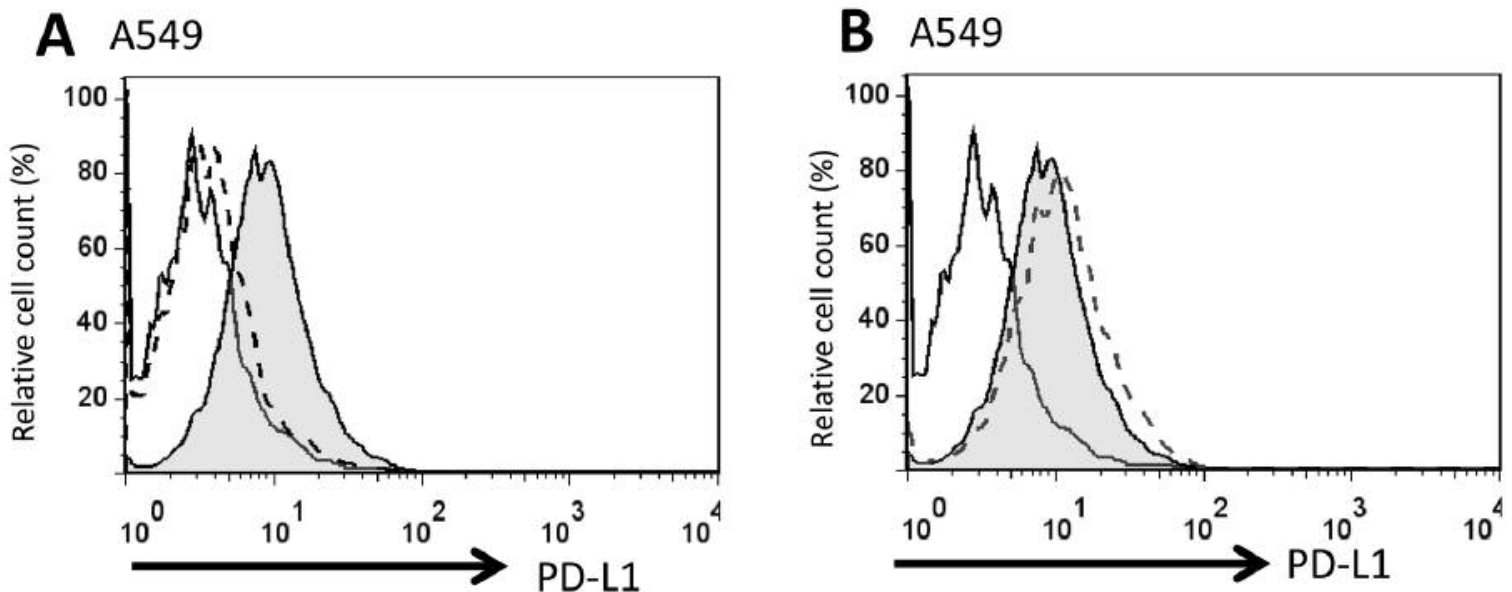

RERF-LC-AI
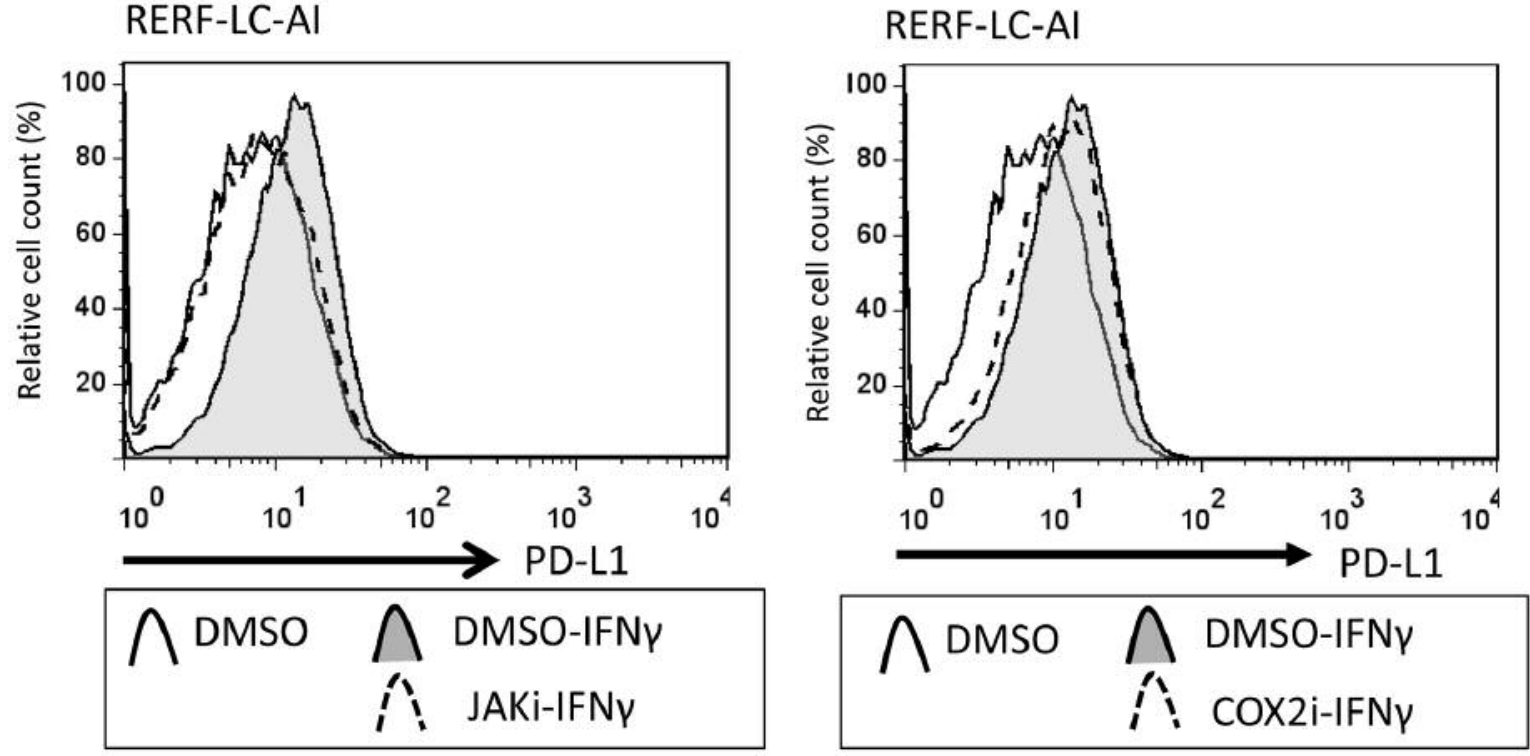

Figure 4. Cyclo-oxygenase-2 (COX2) inhibition (COX2i) failed to block interferon-gamma (IFN- $\gamma$ )-induced programmed cell death-ligand 1 (PDL1) expression in non-small cell lung cancer (NSCLC) cells. NSCLC cell lines pretreated, or not, with $1 \mu$ M of Janus kinase inhibitor (JAKi) tofacitinib (A) or $30 \mu \mathrm{M}$ of celecoxib (B) for $2 \mathrm{~h}$ were treated with $0.5 \mathrm{ng} / \mathrm{ml}$ of IFN- $\gamma$ for 24 hours, and then the expression of PD-L1 was assessed by flow cytometry. Representative data from three independent experiments are shown.

3 Freeman GJ, Long AJ, Iwai Y, Bourque K, Chernova T, Nishimura H, Fitz LJ, Malenkovich N, Okazaki T, Byrne MC, Horton HF, Fouser L, Carter L, Ling V, Bowman MR, Carreno BM, Collins M, Wood CR and Honjo T: Engagement of the PD1 immunoinhibitory receptor by a novel B7 family member leads to negative regulation of lymphocyte activation. J Exp Med 192: 1027-1034, 2000.

4 Blank C, Gajewski TF and Mackensen A: Interaction of PD-L1 on tumor cells with PD-1 on tumor-specific T-cells as a mechanism of immune evasion: Implications for tumor immunotherapy. Cancer Immunol Immunother 54: 307-314, 2005.

5 Velcheti V, Schalper KA, Carvajal DE, Anagnostou VK, Syrigos KN, Sznol M, Herbst RS, Gettinger SN, Chen L and Rimm DL: Programmed death ligand-1 expression in non-small cell lung cancer. Lab Invest 94: 107-116, 2014.
6 Shimoji M, Shimizu S, Sato K, Suda K, Kobayashi Y, Tomizawa $\mathrm{K}$, Takemoto $\mathrm{T}$ and Mitsudomi $\mathrm{T}$ : Clinical and pathologic features of lung cancer expressing programmed cell death ligand 1 (PD-L1). Lung Cancer 98: 69-75, 2016.

7 Sun JM, Zhou W, Choi YL, Choi SJ, Kim SE, Wang Z, DolledFilhart M, Emancipator K, Wu D, Weiner R, Frisman D, Kim HK, Choi YS, Shim YM and Kim J: Prognostic significance of PD-L1 in patients with non-small cell lung cancer: a large cohort study of surgically resected cases. J Thorac Oncol 11: 10031011, 2016.

8 Brahmer J, Reckamp KL, Baas P, Crinò L, Eberhardt WE, Poddubskaya E, Antonia S, Pluzanski A, Vokes EE, Holgado E, Waterhouse D, Ready N, Gainor J, Arén Frontera O, Havel L, Steins M, Garassino MC, Aerts JG, Domine M, Paz-Ares L, Reck M, Baudelet C, Harbison CT, Lestini B and Spigel DR: 
Nivolumab versus docetaxel in advanced squamous-cell nonsmall-cell lung cancer. N Engl J Med 373: 123-135, 2015.

9 Borghaei H, Paz-Ares L, Horn L, Spigel DR, Steins M, Ready NE, Chow LQ, Vokes EE, Felip E, Holgado E, Barlesi F, Kohlhäufl M, Arrieta O, Burgio MA, Fayette J, Lena H, Poddubskaya E, Gerber DE, Gettinger SN, Rudin CM, Rizvi N, Crinò L, Blumenschein GR Jr., Antonia SJ, Dorange C, Harbison CT, Graf Finckenstein F and Brahmer JR: Nivolumab versus docetaxel in advanced nonsquamous non-small-cell lung cancer. N Engl J Med 373: 1627-1639, 2015.

10 Herbst RS, Baas P, Kim DW, Felip E, Pérez-Gracia JL, Han JY, Molina J, Kim JH, Arvis CD, Ahn MJ, Majem M, Fidler MJ, de Castro G Jr, Garrido M, Lubiniecki GM, Shentu Y, Im E, Dolled-Filhart $\mathrm{M}$ and Garon EB: Pembrolizumab versus docetaxel for previously treated, PD-L1-positive, advanced nonsmall-cell lung cancer (KEYNOTE-010). Lancet 387: 15401550, 2016.

11 Reck M, Rodríguez-Abreu D, Robinson AG, Hui R, Csőszi T, Fülöp A, Gottfried M, Peled N, Tafreshi A, Cuffe S, O’Brien M, Rao S, Hotta K, Leiby MA, Lubiniecki GM, Shentu Y, Rangwala $\mathrm{R}$ and Brahmer JR: Pembrolizumab versus chemotherapy for PD-L1-positive non-small-cell lung cancer. N Engl J Med 375: 1823-1833, 2016.

12 Dubois RN, Abramson SB, Crofford L, Gupta RA, Simon LS, Van De Putte LB and Lipsky PE: Cyclo-oxygenase in biology and disease. FASEB J 12: 1063-1073, 1998.

13 Chan AT, Ogino S and Fuchs CS: Aspirin and the risk of colorectal cancer in relation to the expression of COX-2. N Engl J Med 356: 2131-2142, 2007.

14 Bucher C, Jordan P, Nickeleit V, Torhorst J and Mihatsch MJ: Relative risk of malignant tumors in analgesic abusers. Effects of long-term intake of aspirin. Clin Nephrol 51: 67-72, 1999.

15 Shimizu K, Okita R, Saisho S, Maeda A, Nojima Y and Nakata M: Prognostic value of COX2 and PD-L1 expression and its relationship with tumor-infiltrating lymphocytes in resected lung adenocarcinoma. Cancer Manag Res 9: 741-750, 2017.

16 Edelman MJ, Watson D, Wang X, Morrison C, Kratzke RA, Jewell S, Hodgson L, Mauer AM, Gajra A, Masters GA, Bedor $\mathrm{M}$, Vokes EE and Green MJ: Eicosanoid modulation in advanced lung cancer: Cyclo-oxygenase- 2 expression is a positive predic $\neg$ tive factor for celecoxib+ chemotherapyCancer and Leukemia Group B Trial 30203. J Clin Oncol 26: 848-855, 2008.

17 Okita R, Wolf D, Yasuda K, Maeda A, Yukawa T, Saisho S, Shimizu K, Yamaguchi Y, Oka M, Nakayama E, Lundqvist A, Kiessling R, Seliger B and Nakata M: Contrasting effects of the cytotoxic anticancer drug gemcitabine and the EGFR tyrosine kinase inhibitor gefitinib on NK cell-mediated cytotoxicity via regulation of NKG2D ligand in non-small-cell lung cancer cells. PLoS One 10: e0139809, 2015.

18 Okita R, Mougiakakos D, Ando T, Mao Y, Sarhan D, Wennerberg E, Seliger B, Lundqvist A, Mimura K and Kiessling R: HER2/HER3 signaling regulates NK cell-mediated cytotoxicity via MHC class I chain-related molecule A and B expression in human breast cancer cell lines. J Immunol 188: 2136-2145, 2012.

19 Mandai M, Hamanishi J, Abiko K, Matsumura N, Baba T and Konishi I: Dual faces of IFN- $\gamma$ in cancer progression: a role of PD-L1 induction in the determination of pro-and anti-tumor immunity. Clin Cancer Res 22: 2329-2334, 2016.
20 Abiko K, Matsumura N, Hamanishi J, Horikawa N, Murakami R, Yamaguchi K, Yoshioka Y, Baba T, Konishi I and Mandai M: IFN- $\gamma$ from lymphocytes induces PD-L1 expression and promotes progression of ovarian cancer. Br J Cancer 112: 15011509, 2015.

21 Zhang X, Zeng Y, Qu Q, Zhu J, Liu Z, Ning W, Zeng H, Zhang $\mathrm{N}, \mathrm{Du} \mathrm{W}$, Chen C and Huang JA: PD-L1 induced by IFN- $\gamma$ from tumor-associated macrophages via the JAK/STAT3 and $\mathrm{PI} 3 \mathrm{~K} / \mathrm{AKT}$ signaling pathways promoted progression of lung cancer. Int J Clin Oncol 22: 1026-1033, 2017.

22 Fehrenbacher L, Spira A, Ballinger M, Kowanetz M, Vansteenkiste J, Mazieres J, Park K, Smith D, Artal-Cortes A, Lewanski C, Braiteh F, Waterkamp D, He P, Zou W, Chen DS, Yi J, Sandler A and Rittmeyer A: Atezolizumab versus docetaxel for patients with previously treated non-small-cell lung cancer (POPLAR). Lancet 387: 1837-1846, 2016.

23 Hida T, Yatabe Y, Achiwa H, Muramatsu H, Kozaki K, Nakamura S, Ogawa M, Mitsudomi T, Sugiura T and Takahashi $\mathrm{T}$ : Increased expression of cyclo-oxygenase 2 occurs frequently in human lung cancers, specifically in adenocarcinomas. Cancer Res 58: 3761-3764, 1998.

24 Hwang D, Scollard D, Byrne J and Levine E: Expression cyclooxygenase-1 and cyclo-oxygenase-2 in human breast cancer. J Natl Cancer Inst 90: 455-460, 1998.

25 Ogino S, Kirkner GJ, Nosho K, Irahara N, Kure S, Shima K, Hazra A, Chan AT, Dehari R, Giovannucci EL and Fuchs CS: Cyclo-oxygenase-2 expression is an independent predictor of poor prognosis in colon cancer. Clin Cancer Res 14: 8221-8227, 2008.

26 Shimizu K, Nakata M, Hirami Y, Yukawa K, Maeda A and Tanemoto K: Tumor-infiltrating FOXP3+ regulatory T-cells are correlated with cyclo-oxygenese- 2 expression and are associated with recurrence in resected non-small cell lung cancer. J Thorac Oncol 5: 585-590, 2010.

27 Groen HJ, Sietsma H, Vincent A, Hochstenbag MM, van Putten JW, van den Berg A, Dalesio O, Biesma B, Smit HJ, Termeer A, Hiltermann TJ, van den Borne BE and Schramel FM: Randomized, placebo-controlled phase III study of docetaxel plus carboplatin with celecoxib and cyclo-oxygenase-2 expression as a biomarker for patients with advanced nonsmall-cell lung cancer: The NVALT-4 Study. J Clin Oncol 29: 4320-4326, 2011.

28 Dai P, Li J, Ma XP, Huang J, Meng JJ and Gong P: Efficacy and safety of COX-2 inhibitors for advanced non-small-cell lung cancer with chemotherapy: a meta-analysis. Onco Targets Ther 11: 721-730, 2018.

29 Liang M, Yang $\mathrm{H}$ and Fu J: Nimesulide inhibits IFN-gammainduced programmed death-1-ligand 1 surface expression in breast cancer cells by COX-2 and PGE2 independent mechanisms. Cancer Lett 276: 47-52, 2009.

30 Botti G, Fratangelo F, Cerrone M, Liguori G, Cantile M, Anniciello AM, Scala S, D'Alterio C, Trimarco C, Ianaro A, Cirino G, Caracò C, Colombino M, Palmieri G, Pepe S, Ascierto PA and Sabbatino F: COX-2 expression positively correlates with PD-L1 expression in human melanoma cells. J Transl Med 15: 46, 2017.

31 Prima V, Kaliberova LN, Kaliberov S, Curiel DT and Kusmartsev S: COX2/mPGES1/PGE2 pathway regulates PD-L1 expression in tumor-associated macrophages and myeloidderived suppressor cells. Proc Natl Acad Sci USA 114: 1117$1122,2017$. 
32 Gowrishankar K, Gunatilake D, Gallagher SJ, Tiffen J, Rizos H and Hersey P: Inducible but not constitutive expression of PDL1 in human melanoma cells is dependent on activation of NFkappaB. PLoS ONE 10: e0123410, 2015.

33 Kondo A, Yamashita T, Tamura H, Zhao W, Tsuji T, Shimizu M, Shinya E, Takahashi H, Tamada K, Chen L, Dan K and Ogata $\mathrm{K}$ : Interferon-gamma and tumor necrosis factor-alpha induce an immunoinhibitory molecule, B7-H1, via nuclear factor-kappaB activation in blasts in myelodysplastic syndromes. Blood 116: 1124-1131, 2010
34 Yang MY, Lee HT, Chen CM, Shen CC and Ma HI: Celecoxib suppresses the phosphorylation of STAT3 protein and can enhance the radiosensitivity of medulloblastoma-derived cancer stem-like cells. Int J Mol Sci 15: 11013-11029, 2014.

Received June 7, 2018

Revised June 21, 2018

Accepted June 27, 2018 